where he entered the banking house of Kuhn, Loeb \& Co., of which he was senior partner at the time of his death.

Although Warburg was a banker, he worked faithfully and effectively to further efforts and institutions for social betterment, especially through education and the care of the unfortunate. He was a commissioner of the Board of Education of New York and a trustee of several schools and colleges. He was in the forefront in working in the public health movement and on the problems of truancy, mentally backward children, and child delinquency. Institutions for aiding the sick and the blind similarly drew on his wealth and his genius for administration. As an expression of his deep appreciation of music and art, he collected valuable musical instruments and paintings, helped support the Stadium Concerts in New York, gave generously to the advancement of the fine arts at Harvard University, and served on the administrative boards of several institutions.

\title{
The Records of a Flour Milling Firm of Rochester, New York
}

Through the courtesy of Mr. W. M. Angle, of Rochester, New York, the Business Historical Society has acquired the papers of the recently liquidated Moseley \& Motley Milling Co., of Rochester, which had ground wheat on the Genesee for almost a hundred years. The federal processing tax hastened the demise of this concern, but its end would no doubt soon have come for other reasons, for both capital and management could find more profitable employment in other industries in Rochester.

The Moseley \& Motley collection is a large one. When shipped, it filled eleven large wooden boxes. The materials acquired by the Society were selected from practically complete records dating from the early 1870's; the earlier papers of the firm were not available, since they were treasured by an elderly woman as records of an ancestor.

In this case, as so often in considering the preservation of business records, it was difficult to decide what to save. It was impracticable and obviously unnecessary to retain everything. But what should be saved? Working on the third floor of the vacant old mill on the banks of the Genesee, with the aid of an aged employee of the firm and in the company of the official mouser of the mill, the writer had to take care not to yield to the spirit of the place and select too 
liberally. All the ledgers, journals, and trial balances were chosen down to recent years, for which the main accounting books, together with the minute book of $1888-1935$, were temporarily reserved by the company for legal reasons. Generous selection was made from correspondence received, while the bound fimsy copies of letters sent, which were usually brief and of a routine nature, were saved for only every five or ten years. Samples were selected of sales records, invoices, payrolls, cash receipts, wheat purchases, and other material which was similarly of a routine and detailed nature and which was summarized in the main account books.

The Moseley \& Motley Milling Co. began its work near the middle of the past century. Just before the Civil War, a young employee bought a partnership in the firm with $\$ 500$, it is said, which his wife had thriftily saved from her small weekly household allowance. This small concern soon, however, felt the effect of war demand and war prices; the war brought it both work and prosperity. Apparently with the usual ups and downs, the firm continued to grow, and in 1888 it was incorporated with a capital of $\$ 155,000$.

These papers present a rare source for the study of an important and somewhat unique industry over a long period. The Moseley \& Motley firm had its beginnings when Rochester shared with St. Louis first place in American flour-milling. The water power of the Genesee River, excellent facilities for transportation by lake and canal, and the rich wheat fields of the adjacent country had presented opportunities which enterprising millers had exploited with good results. After 1850, however, Rochester felt the competition of the wheat and the millers of the Mississippi country, and before long the millers on the Genesee had to turn to the West for wheat. Between 1870 and 1890, moreover, the rapid improvement in the technique and the organization of milling at Minneapolis, which had the advantage of closeness to virgin wheat fields, bore heavily on the profits of Rochester millers. Since 1904, Rochester has had to meet the rising strength of the milling of its neighbor city, Buffalo. For some time the mills at Rochester continued to grind flour, but the passing of Moseley \& Motley brought the end of a once significant industry on the Genesee.

It is interesting to remember at this time that the great industrial city, which Rochester now is, derived its first large industrial capital and experience in management from flour-milling. Mr. W. M. Angle, himself, who was born into the Moseley \& Motley firm and was its last president, is now an executive of Stromberg-Carlson. 
What were the policies and what was the nature of the management which kept the Moseley \& Motley Milling Co. alive and even made it profitable over a long period which was marked by several severe depressions in business and severe competition from the virgin wheat regions? Only a careful study of the firm's papers can answer that question. A cursory perusal of some of the records points to a number of possible answers. First of all, the careful management of what was in reality a family institution with strong personal relations and loyalty throughout the concern seems to have served to keep costs at a minimum. The mill, moreover, always sought to give close attention to the needs of local bakers and consumers. And, lastly, it always endeavored to produce a high quality of flour. In the distant market, especially, which this relatively small firm could reach only through brokers and commission men, its product could stand only on its quality.

It is to be hoped that someone will soon make a careful study of the records of this concern, which lived such a long time under rapidly and drastically changing conditions. Such a study would not only add to our knowledge of the history of the flour-milling industry, but it should, also, throw interesting light on the management of the smaller firm in a highly competitive and mobile industry.

Henrietta M. Larson Harvard University 